\title{
Characterization of a cleavable fusion of human CYP24A1 with Adrenodoxin reveals the variable role of hydrophobics in redox partner binding
}

Natalie Jay, Sean R. Duffy, D. Fernando Estrada*

Department of Biochemistry, University at Buffalo, Buffalo NY 14203

*Corresponding author: dfestrad@buffalo.edu, (716) 829-2767 
A

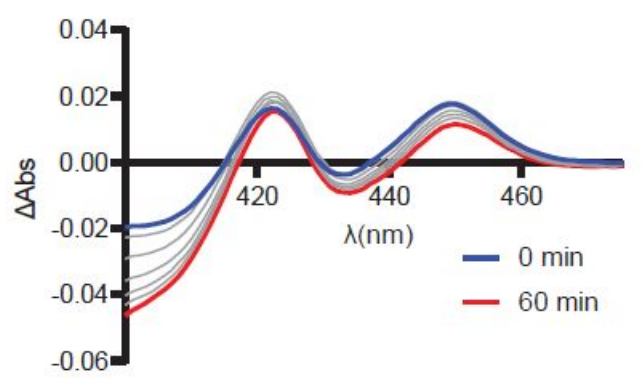

B

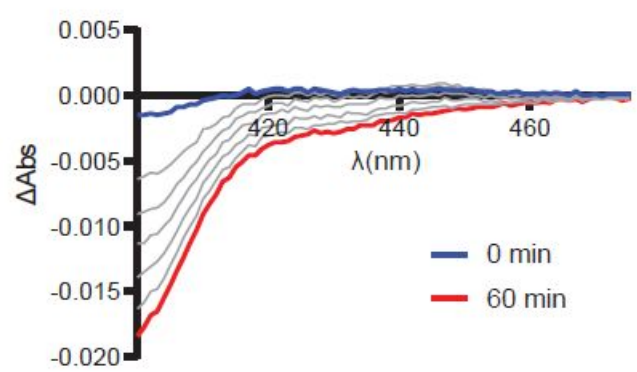

Figure S1. CO-difference spectra from cell lysate from expression of (A) hCYP24A1_hAdx or (B) hCYP24A1. Difference spectra were developed over 60 minutes. 


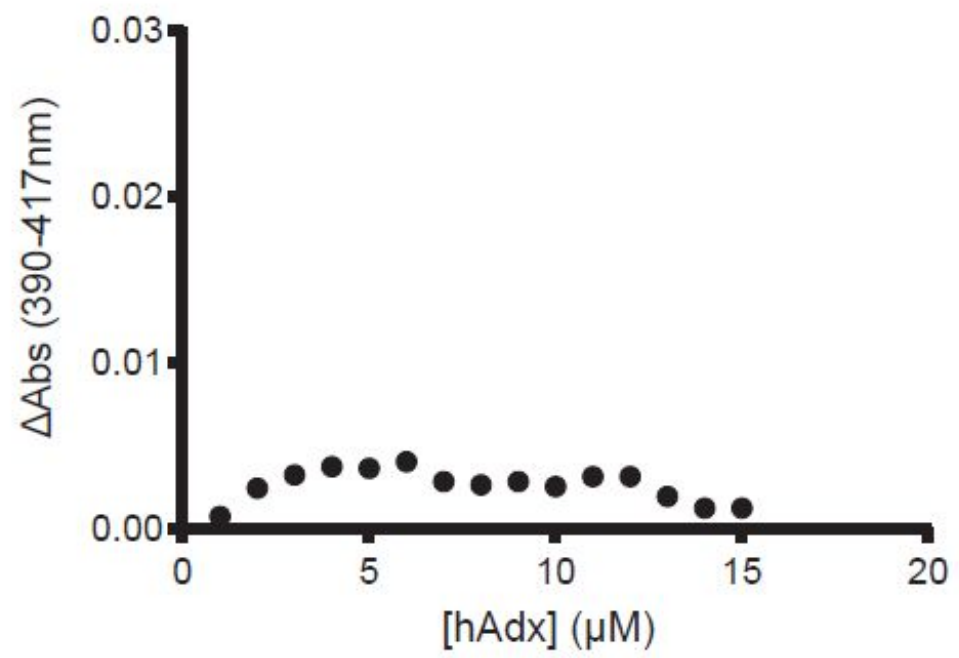

Figure S2. Absorbance changes in $1 \mu \mathrm{M}$ hCYP24A1 as a result of titration with hAdx. 

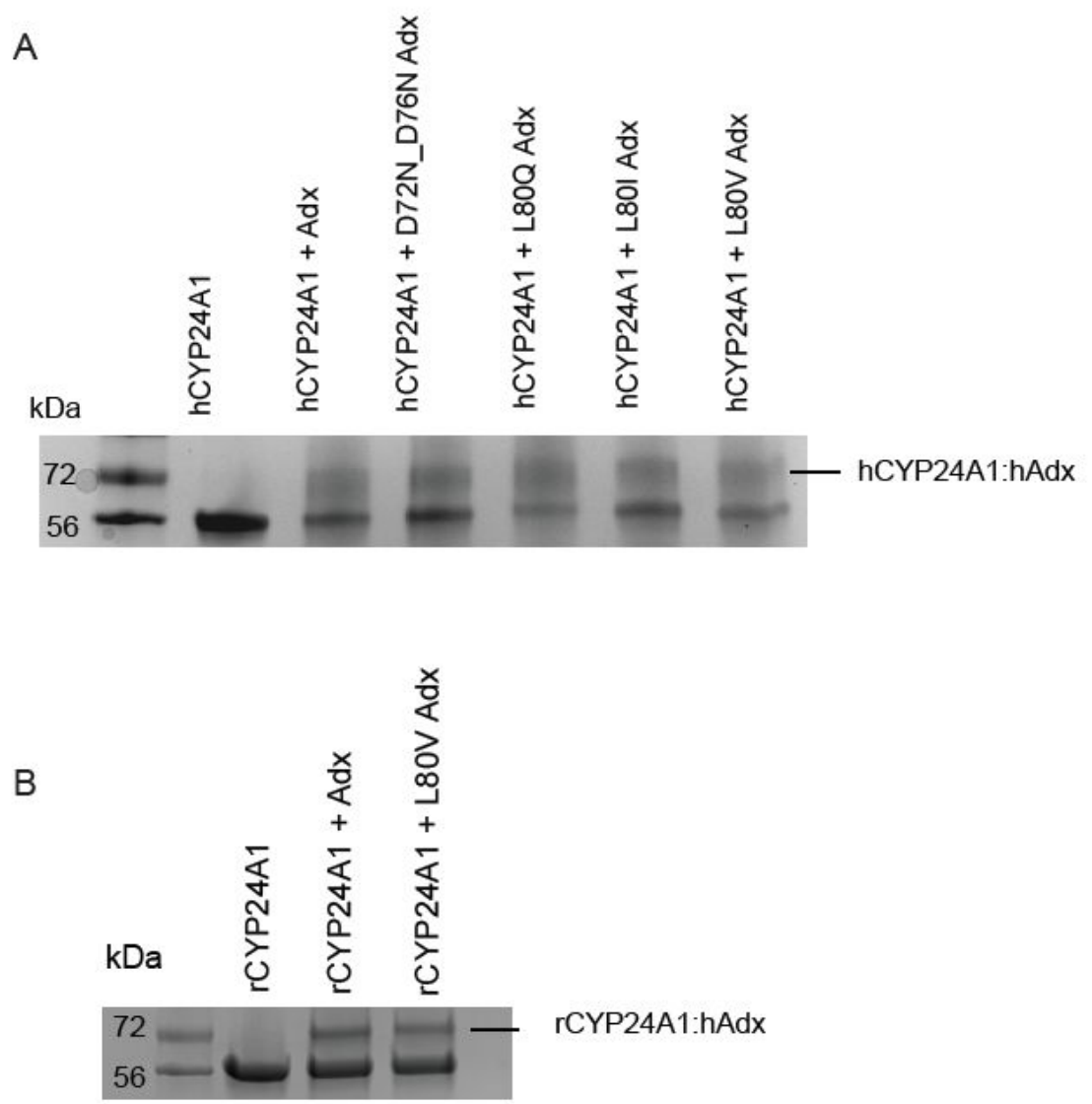

Figure S3. Complex formation between CYP24A1 and Adx mutants. EDC crosslinking with (A) human CYP24A1 or (B) rat CYP24A1. 